\title{
THE NET VALUE CONTRIBUTION TO HUMAN CAPITAL EMPLOYMENT, BY FOREIGN-OWNED FIRMS, IN SOUTHEAST MANUFACTURING INDUSTRIES
}

\author{
Walt Schubert*
}

The southeast has experienced an influx of foreign direct investment in recent years. ${ }^{1}$ This paper is designed to explore the net contribution, by foreign-owned firms, to the value of human capital employed in the southeast. $^{2}$

We will begin by identifying the importance of skilled labor to foreignowned firms. Secondly, we will construct and empirical model. Next, we will apply our model to the available data. We will conclude by reporting on the significance of our results.

\section{Skilled Labor and Foreign Direct Investment}

Foreign-owned firms are at a disadvantage vis-a-vis their domestic rivals. This is true because there are real or potential costs to the foreign-owned firm over and above the cost of production. These costs include the logistical problems of locating far from the parent company, possible constraints on profit repatriation, and the difficulties of obeying two sets of antitrust laws. It is necessary, therefore, that the foreign-owned firm have some special advantages that allow it to compete against domestic firms. Proprietary knowledge refers to advantages that a firm possesses, such as superior managerial or productive techniques, that enable it to overcome the disadvantages of producing in a foreign nation. It is generally skilled workers that produce and employ these advantages. ${ }^{3,4}$ We expect, consequently, to find that foreign-owned firms are located in industries where proprietary knowledge, and, therefore, highly, skilled personnel are an essential part of the firm.

\section{The Model}

We want to measure the net contribution to the value of human capital employed in the southeast by foreign-owned firms. We begin by dividing the jobs listed in the Census of the Population: 1970 into six skill categories. Our six categories are:

*Assistant Professor, Department of Economics, Clemson University, Clemson, South Carolina. 
1. Professional, Technical and Kindred Workers

2. Managers and Administrators

3. Craftsmen and Kindred Workers

4. Sales, Clerical, and Service Workers

5. Operatives (Semi-skilled Workers)

6. Laborers (Unskilled Workers)

Workers in skill categories 1,2 , and 3 are considered to be in the human capital category. ${ }^{\mathbf{5}}$

We then measure the value of the skills being performed. Using 1970 wage and employment data from the Census of the Population: 1970, we can weight the components of our various skill classes in order to obtain a weighted average wage, for each skill class. ${ }^{6}$

We will calculate results based on two different assumptions about what domestic investment would have looked like in the absence of the foreign direct investment that actually took place. In the first case, we assume that foreign direct investment totally supplements domestic direct investment. That is, in the absence of foreign direct investment, no additional domestic investment would be forthcoming. In the second instance, we assume that in the absence of foreign direct investment, domestic direct investment would have totally substituted for foreign investment to the extent that employment would remain constant, but, that the domestic investment would have been distributed according to the historical domestic investment mix. This alternative holds total employment constant, but allows the skill distribution to vary.

We begin by calculating the average direct skill requirements needed to produce a fixed amount of value-added. ${ }^{7}$ We assume that production functions are simple linear combinations of factors, that factors are perfectly divisible and that there are no scale effects. ${ }^{8}$ Using value-added data from the Annual Survey of Manufacturers 1970-1971 and skill data from the Census of the Population: 1970, we can find the quantity in man-years, of each skill, necessary to produce one million dollars of value-added in each industry. ${ }^{9}$ This yields a skill coefficient matrix. Secondly, we find the value-added, of foreign-owned firms, in the industries under observation. ${ }^{10}$ This yields a value-added vector.

Multiplying the skill coefficient matrix by the value-added vector yields an employment vector. The vector indicates the amount of each skill required by foreign-owned firms to produce their value-added. Multiplying the number of workers, in each skill category, by their respective wages yields the value of employment, by skill, of foreign-owned firms.

\section{Empirical Results}

Under the assumptions of the supplemental model, the value of employment of foreign-owned firms is $\$ 767,537,870$. Subtracting the value of employment of skill 4,5 , and 6 yields the net value of human capital employment, $\$ 328,662,961$ (Table 1 Column 1).

In order to find the net contribution to the value of human capital employed by foreign-owned firms using the substitution model, we must 
TABLE 1

Value of Employment, By Skill

1

$\$ 120,706,962$

Professional, Technical and Kindred Workers

Managers and

Administrators

Craftsmen and

Kindred Workers

Sales, Clerical and

Service Workers

Operatives

Laborers
$\$ 45,160,362$

$\$ 162,795,637 \quad \$ 146,731,327$

$\$ 101,869,422 \quad \$ 83,452,400$

$\$ 18,417,022$

$\$ 311,174,847$

$\$ 354,098,434$

$\$-42,923,587$

$\$ 25,830,610$

$\$ 34,066,630$

$\$-8,236,020$

Derived from the following sources:

U. S. Bureau of the Census, Annual Survey of Manufacturers 1970-1971, (Washington, DC: U. S. GPO 1973).

U. S. Bureau of the Census, Annual Survey of Manufacturers 1974-1975, (Washington, DC: U. S. GPO 1977).

U. S. Bureau of the Census, Census of the Population: 1970 Vol. 1 Characteristics of the Population, (Washington DC: U. S. GPO, 1973), pts. 2, 12, 19, 26, 35, 42, 44, and 48.

U.S. Department of Commerce, Report to the Congress, Foreign Direct Investment in the United States, Vol. 2, (Washington, DC: U. S. GPO, 1977).

calculate the value of the employment released by the replaced foreignowned firms, assuming those workers, consequently, were employed by domestic firms. ${ }^{11}$ The results are reported in Table 1 Column 2. Subtracting these values from the value of employment, of foreign-owned firms, yields net employment by skill. This information is reported in Table 1 Column 3. The net value of employment, resulting from the presence of foreign-owned firms is $\$ 46,388,393$. Since net total employment is zero, foreign-owned firms must employ, on average, workers of greater value. The net contribution to the value of human capital employment is $\$ 79,130,978$.

The results presented above were dependent on the assumption that 1970 skill data was valid for 1974 production requirements. ${ }^{12}$ Our 1970 technical coefficients led us to conclude that foreign-owned firms required more workers than they actually employed. We, therefore, recalculated the data, adjusting it for either productivity improvements or capital for unskilled labor substitution. ${ }^{13}$ The productivity adjusted results showed 
the net value of human capital, under the supplemental model to be $\$ 284,443,943$, and under the substitution model to be $\$ 67,361,968$. The capital adjusted results, for the supplemental model, shows the net value of human capital to be $\$ 328,622,961$ and for the substitution model to be $\$ 89,320,961$. There was, then, no qualitative change in our results.

\section{Conclusion}

The United States has been shown to have a comparative advantage in the production of skill intensive goods. ${ }^{14}$ That is, the United States has an abundance of skilled labor. Based on this knowledge, it might be expected that little gain, in human capital growth, could be expected from hosting foreign direct investment. This study indicates the importance of taking a regionalized approach to the study of foreign direct investment effects. Our results indicate that, on average, in the southeast, foreign-owned firms are located in more skill intensive industries than are domestic firms, where skill levels are measured in value terms. Southeastern states, generally, suffer from per capita income levels well below the national average. ${ }^{15}$ The influx of foreign direct investment, into the region, has increased per capita incomes to levels above what they would have been in the absence of that investment, and consequently, has reduced income differentials between the southeast and other regions. From a general policy viewpoint, the study indicates that foreign direct investment, into relatively lowskilled regions of highly industrialized nations, can lead to human capital growth and help reduce interregional income differentials.

\section{FOOTNOTES}

${ }^{1}$ The Southeast refers to Alabama, Georgia, Kentucky, Mississippi, North Carolina, South Carolina, Tennessee and Virginia.

${ }^{2}$ Foreign-owned firms refers to business entities in which at least 10 per cent of the capital stock is owned by firms chartered outside the United States.

${ }^{3}$ For example see: W. Gruber, D. Mehta, R. Vernon, "The R\&D Factor in International Trade and International Investment of United States Industries," Journal of Political Economy, Vol. 75, Feb. 1967.

${ }^{4}$ Galbraith's theory of the technostructure is particularly applicable. The combination of professionals, managers and craftsmen yield special advantages to the firm.

John Kenneth Galbraith, The New Industrial State. Boston: Houghton and Mifflin, 1970.

${ }^{5}$ Any division of skills is somewhat arbitrary. Nevertheless, skill categories 1,2 , and 3 differ from skill categories 4,5 , and 6 by generally, requiring a greater investment in time and money to obtain the skill level.

${ }^{6}$ The reasons for preferring wages to skill categories per se, for measuring human capital, is two fold. First, there is the problem of classifying skills. There is a wide range of managers, craftsman and so forth. Wage levels may yield a better indication of skill differentials than job titles. Secondly, price theory indicates that wage levels, not job titles, education, or total human capital investment indicate the value of a workers employment to society.

${ }^{7}$ These follow the assumptions of Leontief and Keesing
Donald Keesing, "Labor Skills and International Trade: Evaluating Many Trade Flows with a Single Measuring Device." Review of Economics and Statistics, 1965.

Wassily Leotief, "Domestic Production and Foreign Trade: The American Capital Position Re-examined." Readings in International Economics, American Economic Association. Homewood, Illinois: Irwin, 1969, Chapter 39.

${ }^{8}$ Direct requirements are superior to indirect requirements because they reflect the actual employment of foreign-owned firms. Indirect requirements suffer from causation problems as well as problems of isolating exactly where inputs are coming from.

${ }^{9}$ This is done by finding the ratio of total man-years, by skill, by industry, to the total value-added in that industry. This yields a matrix of technical coefficients, indicating the quantity, in man-years of each skill necessary to produce a fixed amount of value-added.

${ }^{10}$ Derived from: U. S. Department of Commerce. $R e-$ port to the Congress, Foreign Direct Investment in the United States. Washington, DC: U. S. GPO Vol. 2 (Supplement).

${ }^{11}$ The released employment, due to the elimination of foreign-owned firms, is distributed to domestic industries, according to the historical value-added mix of domestic-owned firms. Within each industry, the workers are distributed according to the weights of the technical coefficients.

${ }^{12}$ In depth skill data is reported only in the 10 year census. Extensive foreign direct investment data was reported only for 1974 . 
${ }^{13}$ Productivity adjustments assumed all skill categories experienced productivity changes in identical proportion.
${ }^{14}$ Op cit. Donald Keesing.

${ }^{15} \mathrm{U}$. S. Bureau of the Census, Statistical Abstracts of the United States: 1977. (98th edition). Washington, DC, 1977.

\section{BIBLIOGRAPHY}

1. Galbraith, John Kenneth. The New Industrial State. Boston: Houghton and Mifflin, 1970.

2. Gruber, W., Mehta, D., Vernon, R. "The R\&D Factor in International Trade and International Investment of United States Industries." Journal of Political Economy, Vol. LXXV 1967.

3. Keesing, Donald. "Labor skills and International Trade: Evaluating Many Trade Flows with a Single Measuring Device." Review of Economics and Statistics. 1965.

4. Leontief, Wassily. "Domestic Production and Foreign Trade: The American Capital Position Re-examined." Readings in International Economics, America Economic Association. Homewood, Illinois: Irwin, 1969. Chapter 39 .
5. U. S. Bureau of the Census. Annual Survey of Manufacturers 1970-1971. Washington, DC. U. S. GPO, 1973.

6. U. S. Bureau of the Census. Annual Survey of Manufacturers 1974-1975. Washington, DC: U. S. GPO, 1977.

7. U. S. Bureau of the Census. Census of the Poprulation 1970: Vol. I, Characteristics of the Population. Washington, DC: U.S. GPO, 1973, Pts. 2, 12, 19, 26, 35, 42, 44, 48.

8. U. S. Bureau of the Census. Statistical Abstracts of the United States: 1977. (98th edition). Washington, DC, 1977.

9. U. S. Department of Commerce. Report to the Congress, Foreign Direct Investment in the United States. Washington, DC: U. S. GPO, Vol. 2. 